Article

\title{
Strengthening the Voice of Persons with Mental Health Problems in Legal Capacity Proceedings
}

\author{
Marie Fallon-Kund ${ }^{1,2, *}$ and Jerome Bickenbach ${ }^{2}$ \\ 1 Department of Health Sciences and Health Policy, Faculty of Humanities and Social Sciences, \\ University of Lucerne, Frohburgstrasse, 6002 Lucerne, Switzerland \\ 2 Swiss Paraplegic Research, Guido A Zächstrasse 2, 6207 Nottwil, Switzerland; \\ jerome.bickenbach@paraplegie.ch \\ * Correspondence: marie.fallon-kund@paraplegie.ch; Tel.: +41-419-396-578
}

Academic Editor: Anna Arstein-Kerslake

Received: 24 February 2016; Accepted: 24 June 2016; Published: 29 June 2016

\begin{abstract}
Despite the standards set out by the United Nations Convention on the Rights of Persons with Disabilities (CRPD), states are reluctant to put an end to substitute decision-making regimes all at once. Persons with mental health problems are particularly affected by such regimes that are instituted by independent authorities through legal capacity proceedings. In order to allow the person to express their will and preferences throughout the proceedings, the right to be heard is of primary importance for the person concerned. The objective of this paper is to review the essential support mechanisms as well as procedural accommodations for the implementation of an equal and effective right to be heard for persons with mental health problems. Fulfilling the right to be heard in legal capacity proceedings is a step towards more individualized regimes that promote the autonomy of the person.
\end{abstract}

Keywords: mental health; legal capacity proceedings; right to be heard

\section{Introduction}

This paper addresses the gap between current practices regarding legal capacity as well as substitute decision-making and the standards set out by the United Nations Convention on the Rights of Persons with Disabilities (CRPD), from a procedural point of view. Most, if not all, state parties to the CRPD still legally allow for the possibility to restrict a person's legal capacity and appoint a third person who is able to take decisions in the "best interests" of the person concerned regarding property, finances or other personal matters (such as housing) ([1]; [2], p. 25). Such legal capacity proceedings are also known as proceedings regarding guardianship, curatorship, and protection of adults. According to the first general comment of the CRPD Committee, interpreting Article 12 of the Convention, guardianship constitutes substitute decision-making and must be abolished ([3], paras. 9, 29).

Throughout legal capacity or guardianship proceedings a person's capacity is generally assessed or the assessment made by a medical doctor evaluated. Although capacity assessments might be necessary in certain cases of compulsory intervention as "the recognition of equal human dignity may sometimes require limits on the right to self-determination" [4], these assessments as well as involuntary treatment proceedings, that are usually regulated in separate mental health laws, are not the primary focus of the study.

Indeed, this article specifically focuses on the right to be heard for persons with mental health problems in legal capacity proceedings. A variety of terms are used for people with mental health problems or psychosocial disabilities. According to the European Agency for Fundamental Rights and in the absence of a common terminology, we will refer to them as "persons with mental health problems"' ([5], p. 10). 
We start by referring to increasing critical commentary on the interpretation of Article 12 by the CRPD Committee and by highlighting the discrepancies between the CRPD Committee and national practices regarding legal capacity. We focus on how authorities appoint external decision-makers and look at previous studies that show a lack of participation on the part of persons concerned in proceedings. Then we set out what is understood as the right to be heard and its significance from the person's perspective. We further analyze what would be required for the implementation of an equal and effective right to be heard and look at whether the identified components are legally provided across a sample of eight countries in Europe. We argue that if a person is effectively heard in legal capacity proceedings, there is an increased probability that the competent authority will adopt least restrictive, individualized measures and thus promote the autonomy of persons concerned. These procedural issues, as noted in Article 13 of the CRPD, are non-negligible in light of current practices and the powers conferred to authorities dealing with the legal capacity proceedings. These authorities are legal or administrative bodies composed of a single decision-maker or multidisciplinary panel.

\section{Background}

The purpose of the Convention on the Rights of Persons with Disabilities is to promote, protect and ensure the full and equal enjoyment of all human rights and fundamental freedoms by all persons with disabilities, and to promote respect for their inherent dignity. The Convention applies to persons who have long-term physical, mental, intellectual or sensory impairments, which in interaction with various barriers may hinder their full and effective participation in society on an equal basis with others. Adopting a human rights perspective on mental health, the Convention places a particular emphasis on individual autonomy and freedom to make one's own choices. Furthermore, the CRPD underlines the importance of support for and inclusion of adults in decisions affecting them ([6], Article 1).

Article 12 of the CRPD on the right to equal recognition before the law is pivotal in this regard as its second paragraph establishes a right to the enjoyment of legal capacity for persons with disabilities on an equal basis with others. Legal capacity has generally been defined as consisting of two components: legal standing - the right to be a holder of rights and duties—and legal agency-the right to act upon these rights and to have them recognized by law [7]. Article 12.3 further states that all persons should be given access to support in order to exercise the right to legal capacity, i.e., supported decision-making regimes must be available to all. This is confirmed by the interpretation of Article 12 given by the first general comment of the CRPD Committee. The Committee also underscored that legal capacity and mental capacity are distinct concepts: mental capacity refers to the decision-making skills of a person, which naturally vary from one person to another and may be different for a given person depending on many factors, including environmental and social factors; but legal capacity does not vary and is a human right ([3], paras. 9, 29). Finally, the Committee states that "persons with cognitive or psychosocial disabilities have been, and still are, disproportionately affected by substitute decision-making regimes and denial of legal capacity" and explicitly calls for the abolishment of guardianship and other forms of substitute decision-making regimes ([3], paras. 9, 29).

Recently, the professional mental health community, as well as legal practitioners and academics have come out in opposition to this strong interpretation of Article 12 [8-11]. These comments acknowledge that the CRPD is exemplary in many respects and underline the importance of promoting the human rights of persons with disabilities and opposing paternalistic forms of substitute decision-making that ignore the views of persons with disabilities. However, it is increasingly being argued that the ambiguities of the CRPD, especially in light of General Comment 1, are highly problematic for progress towards the rights of persons with disabilities. In addition, it is argued that this Comment failed to give a balanced interpretation of article 12.

Even though some states parties have modified their legal capacity laws, they have been reluctant to discontinue guardianship and other substitute decision-making regimes all at once. Indeed, upon ratification of the Convention, several states made declarations or reservations with regard to Article 12 of the CRPD. These states expressed their intention to follow the Convention in a way 
that allows for restrictions of legal capacity in certain circumstances, for example in cases where protective measures "are necessary, as a last resort and subject to safeguards" [12]. Complying with the standards as interpreted by the CRPD Committee is thus proving to be a challenge at the national level. Currently, no jurisdiction in the world can claim to be fully compliant with Article 12 of the CRPD, and countries still regulate proceedings instituting substitute decision-making regimes [1,2], which allow a decision-maker to make decisions for the person based upon what is believed to be in "the best interests" of the person concerned, even if opposed to the person's will and preferences ([3], paras. 27-28). This despite the clear language of article 12.4:

States Parties shall ensure that all measures that relate to the exercise of legal capacity provide for appropriate and effective safeguards to prevent abuse in accordance with international human rights law. Such safeguards shall ensure that measures relating to the exercise of legal capacity respect the rights, will and preferences of the person (...)

Article 12.4 is clear that the state cannot proceed in a manner that is against a person's will and preferences. The general comment further strengthens this by insisting that that the 'will and preference' test must replace the 'best interests' test to ensure that persons with disabilities enjoy the right to legal capacity on an equal basis with others ([3], paras. 27-28).

It is argued that "the first thing that a political authority should do is to put in the supports that enable individuals to make decisions, rather than take away this opportunity and do the easier thing of letting another person make the decision for them" ([13], p. 90). This opportunity is often removed in legal capacity proceedings conducted by independent authorities, generally judicial authorities such as courts or tribunals. Procedural rights operate as safeguards throughout these proceedings, and this is where Article 13 of the CRPD comes into play. It establishes a right to an equal and effective access to justice for persons with disabilities, which includes being able to participate in the proceedings. An equal participation means that no distinction, exclusion or restriction on the basis of disability which has the purpose or effect of impairing or nullifying participation may occur ([6], Article 2). An effective role as a direct or indirect participant in legal proceedings might require the provision of procedural and age-appropriate accommodations as referred to in article 13. These accommodations are necessary and appropriate adjustments made by the authorities in the justice system to treat a person as a subject of rights and not as an object of protection ([14], p. 95). However, accommodations should not impose a disproportionate or undue burden on the authorities ([6], Article 2). Implementing an equal and effective right to be heard would provide persons with support in order to allow them to express their will and preferences in legal capacity proceedings. Read in conjunction with Article 12, persons with mental health problems should thus be guaranteed the necessary support and accommodations in order to participate in proceedings, including legal capacity proceedings ([15], p. 103).

Legal proceedings on mental health issues are often not perceived to be fully inclusive of the person concerned. Previous studies demonstrate a lack of participation and empowerment of persons with mental health problems in judicial decision-making processes as well as too much decision-making power granted to legal authorities, which perhaps places excessive emphasis on protection and not enough on the autonomy of the person concerned ([16], p. 10; [17], p. 168). Authorities are reported as lacking awareness of the importance of the roles of power and powerlessness and focusing on the illness rather than the person ([18], p. 43; [19], p. 138). Finally, authorities are thought to perform their activities as formal routine and face-to-face interviews between the person with the mental health problems and the legal authority are exceptional [20]. A kind of mutual alienation is thereby created between competent authorities and the persons involved ([21]; [22], p. 578). Although most of these studies concern legal proceedings on involuntary psychiatric admission or treatment, the findings can be compared to what would prevail in proceedings on legal capacity as these deal with similar questions regarding a person's decision-making capacity.

Discrepancies can thus be noted between the legal standards set out in the CRPD and the current situation. While the paradigm shift from substituted to supported decision-making has not been implemented in states parties, in this paper we depart from the current state of procedural practices to 
consider how the participation of persons with mental health problems might be strengthened by a more rigorous enforcement of the right to be heard. Also, we ask whether this right can contribute to promoting autonomy, or in other words, whether the essence of individual autonomy can be preserved by minimizing decisions taken on behalf of persons with mental health problems.

\section{Right to Be Heard}

The right to be heard has had recognition at the international level. Although the entry into force of the CRPD superseded other instruments such as the 1991 United Nations Principles for the Protection of Persons with Mental Illness and the 1999 Council of Europe, Committee of Ministers Recommendation No R(99)4 on Principles concerning the Legal Protection of Incapable Adults, these instruments outlined various procedural safeguards for mental health related proceedings, such as the "right to attend, participate and be heard personally in any hearing" [23] or "the right to be heard in person in any proceedings which could affect his or her legal capacity" [24]. These instruments have had a major impact on legal capacity laws and proceedings across Europe.

More recent human rights developments regarding the right to be heard can be found throughout case law of the European Court of Human Rights (ECtHR) as referred to within this article. However, we start by establishing what we understand as the right to be heard and its significance from the perspective of the person concerned by legal capacity proceedings.

\subsection{Main Characteristics of the Right to Be Heard}

The right to be heard and express one's views relates to the active inclusion of the person throughout proceedings and is essential for effective participation ([25], p. 11). It implies that the person needs to be allowed to express her concerns and experience that what is said is taken into consideration in the decision-making process ([18], pp. 34, 37; [22], p. 574; [26]). Rather than the expression of concerns, within the scope of this article and in alignment with the CRPD, we understand the expression of a person's will and preferences related to the matters discussed in legal capacity proceedings as constitutive of the right to be heard. It requires competent authorities to personally meet with adults with mental health problems who are the subject of a case and to talk with them rather than about them ([14], p. 49). The person is thus part of the proceedings and able to influence its results through the articulation of their will and preferences. It does not mean, however, that the outcome of the proceedings will align with the will of the person, as the competent authorities are the ones taking the decisions.

The right to be heard needs to be distinguished from the right to be informed or consulted. Informing the person does not actively involve her in a decision-making process and is purely an act of providing someone with facts or information. Consulting goes a step further than informing as the person is actively asked for information or advice. Nevertheless, the facts or information provided by the person do not need to be taken into account, and so consultation can be carried out "purely for the politically correct but ultimately vacuous purpose of legitimizing decisions" [27].

\subsection{Significance of the Right to Be Heard}

Being heard and given the opportunity to participate in legal capacity proceedings is of significant importance for the persons whose rights are affected by the proceedings. Indeed, legal authorities provide people with information about their standing both in the eyes of the law and in society more generally ([28], pp. 443-44). Perhaps no type of hearing more directly threatens a person's equal membership of society than proceedings in which legal capacity is at issue. These proceedings touch upon the very essence of personhood and are key to accessing meaningful participation in society as they deal with a person's decision-making capacity. As stressed by the European Court of Human Rights, "an individual's legal capacity is decisive for the exercise of all the rights and freedoms" $[29,30]$. Moreover, without the participation of the person with mental health problems in decisions affecting them, the outcomes seem to be granted as largesse rather than obtained as of 
right [15]. Throughout its case law, the ECtHR underlines the importance of personal contact in legal capacity proceedings, given the fact that that the person is both the interested party and the main object of the court's examination [29,31]. As a consequence, the Court stresses, "that strict scrutiny (of the decision-making process) is called for where measures that have such adverse effect on an individual's personal autonomy, as deprivation of legal capacity has, are at stake" [32,33].

In addition, people are often most strongly affected by the procedures used to reach the outcomes, or by the judicial process itself, rather than the outcomes themselves [28]. If persons feel that they are able to participate in proceedings, that they are being treated with dignity and respect, and if they view the authorities as trustworthy, then they are more likely to accept the court's decisions ([22], p. 573; [28], p. 439). Being heard and feeling that what is said is taken into account by independent authorities, moreover, facilitates the acceptance of what might at times be highly intrusive outcomes.

\section{Components of an Equal and Effective Right to Be Heard}

In what follows, we assume for the sake of the argument that everyone is capable of expressing their will and preferences in some way, even where that expression is not easily understood and support and accommodations are needed to facilitate this expression [34,35]. Similarly, the ECtHR argued that "the fact that an individual has to be placed under guardianship because he lacks the ability to administer his affairs does not mean that he is incapable of expressing a view on his situation" [36]. We review some of the main components required for the implementation of an equal and effective right to be heard for persons with mental health problems, components that would facilitate the expression of the person's will and preferences. We then apply these components to a sample of national laws in Europe in order to compare the actual state of statutory provision in order to assess whether these provisions provide are feasible framework, given the current state of national practices.

\subsection{Identification of Components}

The components, as represented in Table 1, have been selected based on statutory indicators provided by the European Agency for Fundamental Rights on the right to be heard for children ([25], p. 14). Given that children may also need support and accommodation, these components were selected because they seem relevant to legal capacity proceedings involving persons with mental health problems. The selection and specification of the components was done based on a review of the literature on participation in legal proceedings and the right to be heard as well as case law $[14,15,37]$. The result is a non-exhaustive list of support mechanisms and procedural accommodations, some of which are general and apply to all citizens, while others are specific for persons with mental health problems ([14], p. 45).

Table 1. Framework for an equal and effective right to be heard.

\begin{tabular}{clc}
\hline Concept & & Component \\
\hline & 1. & Right to be heard \\
& 2. & Exclusion criteria do not depend on mental capacity \\
Equal and effective right to be heard & 3. & Right to representation \\
& 5. & Person of trust \\
& 6. & Most favorable setting \\
& 7. & Multidisciplinary authority \\
\hline
\end{tabular}

\subsubsection{Fulfilling the Right to Be Heard and Exclusion Criteria}

First, we look at whether the right to be heard is statutorily provided and whether it contains exceptions. The European Court held that persons are entitled to public oral hearings unless exceptional circumstances justify dispensing with the hearing [38]. As mentioned earlier, the ECtHR 
emphasizes the importance of personal contact with the person concerned by the legal capacity proceedings [29,31-33,39,40]. Exceptional circumstances have been accepted in cases where proceedings concerned exclusively legal or highly technical questions [38]. The Convention on the Rights of the Child (CRC) in turn provides that a child who is capable of forming his or her own views should be provided the opportunity to be heard [41]. This provision does not depend on the decision-making skills of the child. By analogy, exceptions to the right to be heard in legal capacity proceedings must not depend on the mental capacity of the person if equality is the aim. This would constitute a functional approach, which attempts to assess mental capacity and deny legal capacity accordingly. As stated in the general comment, the functional approach may result in the determination that a person's decision-making skills are deficient, which leads to a denial of his or her legal capacity:

It is often based on whether a person can understand the nature and consequences of a decision and/or whether he or she can use or weigh the relevant information. This approach is flawed for two key reasons: (a) it is discriminatorily applied to people with disabilities; and (b) it presumes to be able to accurately assess the inner-workings of the human mind and, when the person does not pass the assessment, it then denies him or her a core human right—-the right to equal recognition before the law ([5], para. 15).

Applied to the right to be heard, such an exclusion from a hearing based on a person's decision-making skills would discriminatorily exclude persons with mental health problems from the right to be heard. A contrario, the waiving of the right to appear and be heard must be established in an unequivocal manner and be attended by minimum safeguards commensurate to its importance [42]. For similar reasons persons should not be forced to attend hearings if they reach an informed decision not to.

\subsubsection{Support Mechanisms: Right to Representation and Person of Trust}

Secondly, support mechanisms and procedural accommodations might be required in order to practically achieve equality and effectiveness and balance out prevalent power relations in legal capacity proceedings. According to the first general comment of the CRPD Committee Comment, support in the exercise of legal capacity in relation to access to justice can take various forms, including recognition of diverse communication methods, allowing video testimony in certain situations, procedural accommodations, the provision of professional sign language interpretation, and other assistive methods ([3], para. 39). Regarding the right to be heard, we can distinguish between support mechanisms at the individual level and procedural accommodations made at the court level. By support mechanisms, we refer to the support of other persons during the proceedings, which can for example take the form of assistance or representation by counsel or by a person of trust accompanying the person throughout the proceedings and beyond.

In a recent judgment, the ECtHR emphasized that in cases of persons with mental health problems, there is an obligation "to ensure afforded, independent representation" in order to fulfill the right of an effective access to a court [43]. Indeed, without adequate representation, the right to equal and effective participation in legal proceedings is likely to be void, especially in matters related to the practice of guardians "as these can be particularly complex, intrusive or far-reaching" [44]. This goes hand in hand with the right to information of the person and a sense of understanding as good preparation with the person will contribute to effective participation and will allow counsel to stand alongside the person and not in their place ([19], p. 136; [28], p. 495; [39]; [45], p. 97). Effective assistance by counsel thus comprehends the representation of the will and preferences of the client [46].

Assistance from a person of trust, freely chosen by the person with mental health problems, can enhance the person's understanding of the proceedings, and make it more likely that the will of the person will be expressed. A person of trust can come from the person's social network or from independent advocacy services. Care must be taken, however, to clearly distinguish the role of the person of trust from that of counsel. Indeed, no undue burden should be put on persons in close 
relationships with the person with mental health problems ([47], pp. 141-42), and legal representation should remain a mandate of the counsel. Nevertheless, the involvement of a person of trust increases the consideration given to the family, friends, and support people including the appreciation of the social network of persons standing before the legal authorities [48,49]. As such, it allows the competent authorities also to take into account the perspectives of others affected by the decisions ([45], p. 100).

\subsubsection{Procedural Accommodations: Most Favorable Setting, Multidisciplinary Authority and Training}

Procedural accommodations, in the sense of necessary and appropriate adjustments in the justice system, can also take various forms. One possibility is to adapt the setting of the hearing to accommodate the person's needs. Another way is to adapt the composition of the competent authorities deciding about legal capacity, by using multidisciplinary panels. This adaptation facilitates a collaborative exchange between members from different disciplines or walks of life. This may also defuse some of the implicit power relations, where, for example too much weight was given to the medical doctor's opinion and not enough to the input from social workers who deal with the persons on a day-to-day basis ([19], p. 138; [45], p. 89). Another procedural accommodation involves explicitly training those working in the administration of justice to involve the person concerned in the proceedings. In Article 13, the CRPD refers to the promotion of appropriate training for those working in the field of administration of justice. Such training would allow, not just the panels of deciding authorities, but also counsels and persons acting as guardians, "to be better informed about the communication needs of clients with mental disabilities and the characteristics associated with different mental disabilities" [44,50]. In addition, an appropriate training might contribute to avoid the temptation to substitute the judgment of those working in the field of administration of justice for the person's judgment [50]. Finally, procedural accommodations can also be to set up less formal proceedings with regular breaks ([14], pp. 4, 55). Although these accommodations might greatly improve how these proceedings are conducted from a human rights perspective, without observational studies, it is difficult to say whether this would be the result.

\subsection{Application across Europe}

We now apply this framework to countries in Europe to determine which components are already statutorily provided. We selected Belgium (BE), the Czech Republic (CZ), England and Wales (E\&W), Finland (FI), Germany (DE), the Netherlands (NL), Spain (ES), and Switzerland (CH) as these countries represent a good geographical coverage and a variety of legal traditions. All of these countries are bound by the evolving standards of the ECtHR. We also took care to include countries that have recently made modifications to their legislation and those that have not. It should be noted that only the Netherlands and Finland have failed to ratify the CRPD, although for both countries they have signed and expressed their intention to comply with its standards.

Table 2 sets out the results of the assessment by component and country. It starts by mentioning the main sources used and the year of the latest revision relevant for this study. The legal provisions expressing the right to be heard in legal capacity proceedings and the other components were found in procedural laws of the eight countries. For the Czech Republic and Switzerland, the right to be heard is set out in the substantial legislation on legal capacity while for Finland it is provided for in both substantial and procedural legislation [51-54]. In England and Wales, it is the 2007 Court of Protection Rules that provides guidance on this matter.

\subsubsection{Fulfilling the Right to Be Heard}

Overall, the regulations refer to a right to be heard in legal capacity proceedings, although this can be given different formulations. Either the person literally has "the right to be heard" (Switzerland) or the right "to exercise his or her right to be heard" (Finland), the court "shall hear" the person (Finland, Germany), the person "will be heard" (Spain), is "convoked to be heard" (Belgium), is given an opportunity to "share his opinion" (Netherlands) or "must have been seen" and his "statement 
heard" or "his opinion obtained" (Czech Republic). In England and Wales the court "may hear" the person, so the right to be heard is not mandatory [51,55-62].

Table 2. Results of the assessment per component and per country.

\begin{tabular}{|c|c|c|c|c|c|c|c|c|}
\hline Framework & BE & $\mathrm{CZ}$ & $\mathbf{E} \& \mathbf{W}$ & FI & DE & NL & ES & $\mathrm{CH}$ \\
\hline Source & $\begin{array}{l}\text { Judicial } \\
\text { Code } \\
2014\end{array}$ & $\begin{array}{l}\text { Civil } \\
\text { Code } \\
2014\end{array}$ & $\begin{array}{l}\text { Court of } \\
\text { Protection } \\
\text { Rules } \\
2007\end{array}$ & $\begin{array}{l}\text { Guardianship } \\
\text { Services Act } \\
1999\end{array}$ & $\begin{array}{l}\text { Act on } \\
\text { Proceedings } \\
\text { in Family } \\
\text { Matters } \\
2009\end{array}$ & $\begin{array}{l}\text { Code of } \\
\text { Civil } \\
\text { Procedure } \\
1994\end{array}$ & $\begin{array}{l}\text { Code of } \\
\text { Civil } \\
\text { Procedure } \\
2015\end{array}$ & $\begin{array}{l}\text { Civil } \\
\text { Code } \\
2013\end{array}$ \\
\hline Fulfilling the right to be heard & $\sqrt{ }$ & $\sqrt{ }$ & $\times$ & $\sqrt{ }$ & $\sqrt{ }$ & $\sqrt{ }$ & $\sqrt{ }$ & $\sqrt{ }$ \\
\hline $\begin{array}{l}\text { Exclusion criteria do not } \\
\text { depend on mental capacity }\end{array}$ & $\sqrt{ }$ & $\sqrt{ }$ & $\sqrt{ }$ & $x$ & $\sqrt{ }$ & $\sqrt{ }$ & $\times$ & $\sqrt{ }$ \\
\hline Right to representation & $\sqrt{ }$ & $\sqrt{ }$ & $\sqrt{ }$ & $\sqrt{ }$ & $\sqrt{ }$ & $\sqrt{ }$ & $\sqrt{ }$ & $\sqrt{ }$ \\
\hline Person of trust & $\sqrt{ }$ & $\sqrt{ }$ & $\times$ & $\times$ & $\sqrt{ }$ & $\times$ & $\times$ & $x$ \\
\hline Most favorable setting & $\sqrt{ }$ & $\sqrt{ }$ & $\times$ & $\sqrt{ }$ & $\sqrt{ }$ & $\sqrt{ }$ & $\times$ & $\times$ \\
\hline Multidisciplinary authority & $x$ & $x$ & $\times$ & $x$ & $\times$ & $\times$ & $\times$ & $\sqrt{ }$ \\
\hline Provision of training & $\times$ & $x$ & $\times$ & $\times$ & $\times$ & $x$ & $\times$ & $x$ \\
\hline
\end{tabular}

\subsubsection{Exclusion Criteria and Dependency on Mental Capacity}

All countries provide for exceptions to the right to be heard. The Czech Civil Code states that the person must be seen unless it is "impossible due to an insurmountable obstacle" [61]. The Spanish Code of Civil Procedure states that the person will be heard if she has enough mental capacity [58]. In Finland, a person without full legal capacity shall exercise the right to be heard if he or she has attained eighteen years of age and is able to understand the significance of the matter [52-54]. In turn, the German Act on Procedures in Family Matters specifically states that "in matters concerning custodianship, the person concerned has the capacity to participate in the proceedings without consideration of his capacity to contract" [57]. Capacity to participate is here separated from mental and legal capacity.

The Belgian Judicial Code states that the person's opinion does not need to be asked in matters related to legal capacity if the person is considered unable to share his or her opinion [59]. This exception is not based on the inability to have an opinion but on the inability to share it. Other exceptions are mainly related to a proportionality criterion or health reasons. In the Netherlands and Switzerland for example, if a matter related to legal capacity is considered secondary or complementary, the hearing does not need to take place, as this would be out of proportion [56,60]. The same reasoning applies to the Finnish exception of the right to be heard, where no hearing needs to take place if the petition is at once rejected as ill-founded [51]. In Belgium, Germany, and Finland, legal authorities can also depart from the right to be heard if there is a risk of detriment to the health of the person, if the hearing is impossible because of the condition of the person, or if it would cause her undue inconvenience [51,57,59].

Consistent with ECtHR case law, exclusions to the right to be heard based on health reasons are mostly determined by the opinion of a medical expert [31]. This is intended to guarantee that this inability is based on an objective assessment. The ECtHR has questioned, however, the quality of medical evidence used in domestic legal capacity cases ([15], p. 117; [31,32]). The CRPD implicitly raises a concern about an overreliance on medical evidence for these determinations ([15], p. 118). It is often all too easy to allege that an adult cannot understand the procedure in order to bypass his or her right to be heard ([14], p. 53; [63], p. 43; [64]). There might, moreover, be a potential conflict of interest if the medical doctor assessing the person's ability to participate in the proceedings is the same doctor who assesses legal capacity. The medical doctor then risks being both judge and party to the proceedings, which violates the right to a fair trial by an independent authority. 


\subsubsection{Right to Representation}

In most countries, a right to representation is statutorily provided. This contrasts with previous findings in other countries where minimal access to counsel is rarely mandated statutorily (or even judicially). However, and although provided for in law, access to counsel is rarely implemented in legal capacity proceedings [64]. Furthermore, the right to representation in legal capacity proceedings is often conferred to public authorities, such as in the Czech Republic, England and Wales, Finland, Germany, Spain, and Switzerland [53,56-58,61,62]. This raises questions with regard to the independency of the representation. Accordingly, the CRPD Committee expressed its concerns with regard to the "the designation of public defenders that treat the person concerned as if they lacked legal capacity" asking whether these are not "patronizing measures" undermining effective support in the decision-making process [65].

\subsubsection{Person of Trust}

Several countries allow for persons of trust to accompany the person concerned into legal capacity proceedings while in Finnish courts more generally, family members can be appointed as support persons in main hearings ([14], pp. 60-61; [53], Section 21). Only Belgium, the Czech Republic and Germany however specifically refer to the possible participation of a person who the concerned person trusts in their legislation ([57], Section 274 (4) 1; [59], Section 1243; [66]).

\subsubsection{Most Favorable Setting}

Five out of the eight countries regulate the possibility of letting the hearing take place at a more favorable setting for the person than the courtroom. In Belgium and the Netherlands, the judge can go to the place where the person resides or where he finds himself, and the German law also states that the hearing can take place in the person's usual environment $[57,59,60]$.

In Finland, the hearing of the person can be arranged outside the main hearing of the court if the person cannot appear in court without considerable inconvenience. In addition, given the sometimes long distances to courtrooms in Finland, the possibility of video hearings is also legally provided for, while the Czech law says that the person can elect the way of communicating his opinion ([14], p. 58; [61], Section 56).

\subsubsection{Multidisciplinary Authority}

Only Switzerland has a multidisciplinary system, instituted when its modified legal capacity legislation entered into force in 2013. The competent legal authority is composed of one legal member able to guarantee a correct application of the law, and, depending on the litigated matter, two other persons who must have the required psychological, social, pedagogical, accounting, actuarial, or medical competencies. The decisions need to be made by at least three members, but the regions can fix a higher number depending on the case ([56], Article 440). Such a system was implemented because of the perceived increasing complexity of psychosocial problems involved in the "protection of adults" and pursuant to the requirement that individualized measures be instituted [67]. The Swiss system allows authorities to obtain a comprehensive understanding of the case. Finally, and although not multidisciplinary, the English Court of Protection and the German Custodianship Court are specialized legal authorities in the sense that they only deal with capacity related cases while authorities in the other countries also deal with other legal matters.

\subsubsection{Provision of Training}

So far, none of the countries specifically regulate the promotion of training for persons working in the field of the administration of justice and involved in legal capacity proceedings. 


\subsection{Preliminary Conclusion}

The application of our framework to a sample of countries in Europe shows that the overall compliance with the statutory components of an equal and effective right to be heard is rather deficient. A limitation here, however, is that we do not assess the concrete implementation of statutory provisions such as the right to representation, on one hand, nor practices such as legal authorities who displace themselves to the person despite the lack of legal provisions, on the other hand. Nonetheless, recently modified legal capacity laws seem to be moving towards more participation of the person with mental health problems in legal capacity proceedings. This is exemplified by the Swiss interdisciplinary legal authorities and by the Belgian, Czech, and German provisions regarding a person of trust. Therefore, it reinforces the idea that the selected components have the potential to be effectively implemented and promote an equal and effective right to be heard for persons with mental health problems. How this can contribute to the autonomy of the persons involved in the legal capacity proceedings is briefly discussed in the final section.

\section{Conclusions}

This article did not go into the question of how authorities can legitimize decisions deviating from a person's will and preferences but rather provided a framework for the implementation of an equal and effective right to be heard, a right we argued was particularly significant for the person involved in legal capacity proceedings. As a further step in promoting the autonomy of the person, we would also need to look at the significance of the right to be heard from the perspective of competent authorities. Arguably, an effective hearing on legal capacity would require authorities to base their decision about legal capacity from different perspectives, going beyond the medical certificate to other evidence and documents in person's file.

In previous years, results of court applications regarding legal capacity have been inflexible and followed an "all or nothing" approach ([47], p. 139). Persons were either placed under plenary guardianship regimes or not provided with any kind of protective measures at all. Competent authorities were said to "rubberstamp the conclusions of the clinical experts", and attorneys often seemed to "act in concert with the judge and clinical experts" [68]. Today, the freedom to make one's own choices is given particular significance across international human rights instruments, most especially the CRPD. This entails that there is a need to individualize the procedures used to make legal capacity determinations, which, we have argued, can only be realized if an effective hearing takes place.

The implementation of the proposed framework allows authorities to hear what a person's will and preferences are in relation to the discussed matters. In short, a person's mental capacity cannot be used solely to exclude her from a hearing. However, if considered necessary and to ensure that the person is provided equal standing before the law, supportive, as well as procedural accommodations need to be provided, such as trained multidisciplinary authorities and more favorable settings. Only in this way can the person's will and preferences be communicated and entail measures tailored to the circumstances of each individual.

Individualized measures would be least restrictive of autonomy in as much as decision-making capacity is preserved in all areas that do not require any type of protection or support. A proper implementation of the proposed framework would thus contribute to closing the gap between the current situation in countries and the standards set out by the CRPD, and to overcome the assumption that, because of mental health problems, people lack will and preferences. In addition, these measures lead to a fundamental rethinking of the foundations of guardianship proceedings ([15], p. 128). As small steps pave the ways to change, an equal and effective hearing is one step in a gradualist approach towards promotion of the autonomy of persons concerned by legal capacity proceedings. 
Acknowledgments: The research was supported by the European Union Seventh Framework Program [FP7/2007-2013] under the project Mental Health Training through Research Network in Europe (MARATONE), Marie Curie Actions-Initial Training Network, Grant Agreement Number 316795. In addition, the authors thank the anonymous reviewers for their helpful suggestions and acknowledge the feedback of Carly M. Toepke and Ivana Ivandic.

Author Contributions: Marie Fallon-Kund and Jerome Bickenbach designed the research and Marie Fallon-Kund analyzed the data. Both authors took part in writing the paper.

Conflicts of Interest: The authors declare no conflict of interest. The founding sponsors had no role in the design of the study; in the collection, analyses, or interpretation of data; in the writing of the manuscript, and in the decision to publish the results.

\section{Abbreviations}

The following abbreviations are used in this manuscript:

CRC Convention on the Rights of the Child

ECtHR European Court of Human Rights

UNCRPD United Nations Convention on the Rights of Persons with Disabilities

\section{References and Notes}

1. European Agency of Fundamental Rights (FRA). Implementing the United Nations Convention on the Rights of Persons with Disabilities (CRPD). Luxemburg: Publication Office of the European Union, 2015, p. 9.

2. European Commission. "Commission Staff Working Document. Accompanying the Communication from the Commission to the European Parliament, the Council, the European Economic Social Committee and the Committee of the Regions. European Disability Strategy 2010-2020: A Renewed Commitment to a Barrier-Free Europe." 2010. Available online: http://eur-lex.europa.eu/legal-content/EN/TXT/PDF/?uri= CELEX:52010SC1324\&from=EN (accessed on 10 February 2016).

3. UN Committee on the Rights of Persons with Disabilities. General Comment No. 1 (2014). Geneva: UN Committee on the Rights of Persons with Disabilities, 2014.

4. Jillian Craigie. "Against a singular understanding of legal capacity: Criminal responsibility and the Convention on the Rights of Persons with Disabilities." International Journal of Law and Psychiatry 40 (2015): 6-14. [CrossRef] [PubMed]

5. European Agency of Fundamental Rights (FRA). Legal Capacity of Persons with Intellectual Disabilities and Persons with Mental Health Problems. Luxemburg: Publication Office of the European Union, 2013.

6. UN General Assembly. "Convention on the rights of persons with disabilities (A/RES/61/106)." 2006. Available online: http://www.un.org/disabilities/convention/conventionfull.shtml (accessed on 10 February 2016).

7. International Disability Alliance. "Legal Opinion on Article 12 of the CRPD." 2008. Available online: http:/ / www.internationaldisabilityalliance.org/en/ida-position-papers-and-statements (accessed on 10 February 2016).

8. Paul S. Appelbaum. "Protecting the Rights of Persons with Disabilities: An International Convention and Its Problems." Psychiatric Services 67 (2016): 366-68. [CrossRef] [PubMed]

9. John Dawson. "A realistic approach to assessing mental health laws' compliance with the UNCRPD." International Journal of Law and Psychiatry 40 (2015): 70-79. [CrossRef] [PubMed]

10. Jos Dute. "Should Substituted Decision-Making Be Abolished?" European Journal of Health Law 22 (2015): 315-20. [CrossRef] [PubMed]

11. Melvyn Colin Freeman, Kavitha Kolappa, Jose Miguel Caldas de Almeida, Arthur Kleinman, Nino Makhashvili, Sifiso Phakathi, Benedetto Saraceno, and Graham Thornicroft. "Reversing hard won victories in the name of human rights: a critique of the General Comment on Article 12 of the UN Convention on the Rights of Persons with Disabilities." Lancet Psychiatry 2 (2015): 844-50. [CrossRef]

12. United Nations Treaty Collection. "Convention on the Rights of Persons with Disabilities: Declarations and Reservations." 2007. Available online: https://treaties.un.org/Pages/ViewDetails.aspx?src=TREATY\& mtdsg_no=IV-15-a\&chapter=4\&lang=en (accessed on 10 February 2016).

13. Gerard Quinn. "Interview: Promoting a paradigm shift: ERT talks with Gabor Gombos and Gerard Quinn about the UN CRPD and its optional protocol." The Equal Rights Review 2 (2008): 90. 
14. AJUPID. "Comparison of legal systems in access to justice for persons with intellectual disabilities in the following countries: Bulgaria, Finland, France, Hungary, Ireland." 2015. Available online: http:// www.ajupid.eu/images/research/AJuPID\%20FINAL\%20RESEARCH\%20REPORT\%20MAY\%202015.pdf (accessed on 10 February 2016).

15. Lucy Series. "Legal Capacity and Participation in Litigation: Recent Developments in the European Court of Human Rights." In European Yearbook of Disability Law. Edited by Lisa Waddington, Gerard Quinn and Eilionóir Flynn. Antwerp: Intersentia, 2015, vol. 5, pp. 103-28.

16. Patrick Fassbind. “20 mois après l'introduction du nouveau droit de protection: Attentes et réalité-Bilan et perspectives." Paper presented at La protection de l'enfant et de l'adulte en pleine mutation—Expériences pratiques des 20 derniers mois, Bienne, Switzerland, 2-3 September 2014. Available online: http:/ /www. kokes.ch/assets/pdf/fr/aktuell/2014_R_7_Fassbind_F.pdf (accessed on 10 February 2016).

17. Terry Carney, and David Tait. The Adult Guardianship Experiment: Tribunals and Popular Justice. Sydney: Federation Press, 1997.

18. European Agency of Fundamental Rights (FRA). Involuntary Placement and Involuntary Treatment of Persons with Mental Health Problems. Luxemburg: Publication Office of the European Union, 2012.

19. Terry Carney, Fleur Beaupert, Julia Perry, and David Tait. "Advocacy and Participation in Mental Health Cases: Realisable Rights or Pipe-Dreams?" Law in Context 26 (2008): 125-47.

20. Thomas W. Kallert. "Coercive Treatment in Psychiatry. A Human Rights Issue?" In Mental Health and Human Rights: Vision, Praxis, and Courage. Edited by Michael Dudley, Derrick Silove and Fran Gale. Oxford: Oxford University Press, 2012, p. 343.

21. Danny H. Sullivan, and Paul E. Mullen. "Mental Health and Human Rights in Secure Settings." In Mental Health and Human Rights: Vision, Praxis, and Courage. Edited by Michael Dudley, Derrick Silove and Fran Gale. Oxford: Oxford University Press, 2012, p. 289.

22. Brian G. McKenna, Alexander I. Simpson, John H. Coverdale, and Tannis M. Laidlaw. "An analysis of procedural justice during psychiatric hospital admission." International Journal of Law and Psychiatry 24 (2001): 573-81. [CrossRef]

23. UN General Assembly. "The protection of persons with mental illness and the improvement of mental health care (A/RES/46/119)." 1991. Available online: http:/ /www.un.org/documents/ga/res/46/a46r119.htm (accessed on 10 February 2016).

24. Council of Europe, Committee of Ministers. "Recommendation No R (99) 4 on Principles concerning the Legal Protection of Incapable Adults." 1999. Available online: http://www.coe.int/t/dg3/healthbioethic/ texts_and_documents/Rec(99)4E.pdf (accessed on 10 February 2016).

25. European Agency of Fundamental Rights (FRA). Child-Friendly Justice-Perspectives and Experiences of Professionals on Children's Participation in Civil and Criminal Judicial Proceedings in 10 EU Member States. Luxemburg: Publication Office of the European Union, 2015.

26. Council of Europe, Committee of Ministers. "Recommendation Rec(2004)10 of the Committee of Ministers to member states concerning the protection of the human rights and dignity of persons with mental disorder (Article 20 (1) (i))." 2004. Available online: https://wcd.coe.int/ViewDoc.jsp?id=775685 (accessed on 10 February 2016).

27. Oliver Lewis, and Nell Munro. "The Right to Participation of People with Mental Disabilities in Legal and Policy Reforms." In Mental Health and Human Rights: Vision, Praxis, and Courage. Edited by Michael Dudley, Derrick Silove and Fran Gale. Oxford: Oxford University Press, 2012, p. 585.

28. Tom R. Tyler. "The Psychological Consequences of Judicial Procedures: Implications or Civil Commitment." Southern Methodist University Law Review 46 (1992): 433-48.

29. ECtHR, Shtukaturov v. Russia, 44009/05 (2008) §§ 71-72.

30. ECtHR, Stanev v. Bulgaria, 36760/06 (2012) partly dissenting opinion of judge Kalaydjieva.

31. ECtHR, Lashin v. Russia, 33117/02 (2013) § 82.

32. ECtHR, M.S. v. Croatia, $36337 / 10(2013) \S 97$.

33. ECtHR, X and Y v. Croatia, 5193/09 (2011) § 84, § 109.

34. Eilionóir Flynn, and Anna Arstein-Kerslake. "Legislating personhood: Realising the right to support in exercising legal capacity." International Journal of Law in Context 10 (2014): 81-104. [CrossRef] 
35. Gerard Quinn. "Personhood and legal capacity. Perspectives on the paradigm shift of article 12 CRPD." Paper presented at HPOD Conference, Harvard Law School, Cambridge, MA, USA, February 2010. Available online: http://www.nuigalway.ie/cdlp/staff/gerard_quinn.html (accessed on 10 February 2016).

36. ECtHR, DD v. Lithuania, 13469/06 (2012) § 118.

37. Terry Carney. "Involuntary mental health treatment laws: The 'rights' and the wrongs of competing models?" In Rethinking Rights-Based Mental Health Laws. Edited by Bernadette McSherry and Penelope Weller. Oxford: Hart Publishing, 2010, p. 265.

38. ECtHR, Koottummel v. Austria, 49616/06 (2009) §§ 18-21.

39. ECtHR, Salontaji-Drobnjak v. Serbia, 36500/05 (2009) § 127.

40. ECtHR, Sýkora v. the Czech Republic, 23419/07 (2012) § 107.

41. UN General Assembly. "Convention on the rights of the child (A/RES/44/25, 1989, Article 12)." Available online: http:/ /www.ohchr.org/Documents/ProfessionalInterest/crc.pdf (accessed on 10 February 2016).

42. ECtHR, Poitrimol v. France, 14032/88 (1993) § 31.

43. ECtHR, Ivinovic v. Croatia, 13006/13 (2014) §37.

44. Peter Bartlett, Oliver Lewis, and Oliver Thorold. Mental Disability and the European Convention on Human Rights. Leiden and Boston: Martinus Nijhoff Publishers, 2006, pp. 235-52.

45. Penelope J. Weller. "Taking a reflexive turn: Non-adversarial justice and mental health review tribunals." Monash University Law Review 37 (2011): 81.

46. Michael L. Perlin. “'I Might Need a Good Lawyer, Could Be Your Funeral, My Trial': Global Clinical Legal Education and the Right to Counsel in Civil Commitment Cases." Washington University Journal of Law and Policy 28 (2008): 247-48.

47. Shih-Ning Then. "Evolution and Innovation in Guardianship Laws: Assisted Decision-Making." Sydney Law Review 35 (2013): 133-66.

48. Piers Gooding. "Supported decision-making: A rights-based disability concept and its implications for mental health law." Psychiatry, Psychology and Law 20 (2013): 431-51. [CrossRef]

49. Terry Carney, David Tait, Julia Perry, Alikki Vernon, and Fleur Beaupert. Australian Mental Health Tribunals: Space for Fairness, Freedom, Protection and Treatment. Sydney: Themis Press, 2011.

50. David A. Green. "I'm OK-You're OK: Educating Lawyers to Maintain a Normal Client-Lawyer Relationship with a Client with a Mental Disability." Journal of the Legal Profession 28 (2003): 65-92.

51. Guardianship Services Act 1999 (Finland), Section 74.

52. Administrative Judicial Procedure Act 1996 (Finland), Sections 17-18.

53. Administrative Procedure Act 2003 (Finland), Section 14.

54. Code of Judicial Procedure (Finland), chapter 12, Section 1.

55. Constitution (Switzerland), Article 29.

56. Civil Code 2013 (Switzerland), Articles 447-49.

57. Act on Proceedings in Family Matters and in Matters of Non-contentious Jurisdiction 2009 (Germany), Sections 275-78, 319.

58. Code of Civil Procedure (Spain), Articles 758-59.

59. Judicial Code 2014 (Belgium), Articles 1243-44, 1250.

60. Code of Civil Procedure (the Netherlands), Articles 802, 809.

61. Civil Code 2014 (Czech Republic), Sections 56, 460, 471.

62. Court of Protection Rules 2007 (England and Wales), Sections 9, 143.

63. MDAC. “Guardianship and Human Rights in Serbia.” 2006. Available online: http://www.mdac.info/sites/ mdac.info/files/English_Guardianship_and_Human_Rights_in_Serbia.pdf (accessed on 10 February 2016).

64. Michael L. Perlin. "International Human Rights and Comparative Mental Disability Law: The Universal Factors." Syracuse Journal of International Law and Commerce 34 (2007): 333-57.

65. Committee on the Rights of Persons with Disabilities. "Concluding Observations on the Initial Report of China, Adopted by the Committee at its eighth session (17-28 September 2012) § 23." Available online: http://tbinternet.ohchr.org/_layouts/treatybodyexternal/Download.aspx?symbolno=CRPD\%2fC\% 2fCHN\%2fCO $\% 2 f 1 \% 2 f C o r r .1 \& L a n g=e n$ (accessed on 10 February 2016).

66. Code of Civil Procedure 2014 (Czech Republic), §§ 22-23. 
67. Conseil fédéral Suisse. “Message concernant la révision du code civil suisse (Protection de l'adulte, droit des personnes et droit de la filiation)." Available online: https://www.admin.ch/opc/fr/federal-gazette/2006/ 6635.pdf (accessed on 10 February 2016).

68. Bruce J. Winick. “Therapeutic Jurisprudence and the Treatment of People with Mental Illness in Eastern Europe: Construing International Human Rights Law." New York Law School Journal of International and Comparative Law 21 (2002): 537-72.

(c) 2016 by the authors; licensee MDPI, Basel, Switzerland. This article is an open access article distributed under the terms and conditions of the Creative Commons Attribution (CC-BY) license (http:/ / creativecommons.org/licenses/by/4.0/). 